\title{
Kebijakan Pemberlakuan Politik Demokrasi dan Pengaruhnya Terhadap Kesejahteraan Sosial
}

\author{
Moh. Zaini \\ Program Studi Pendidikan Jasmani Kesehatan dan Rekreasi IKIP Budi Utomo \\ Jalan Simpang Arjuno 14B Malang \\ pojur_zen@yahoo.com
}

\begin{abstract}
Democracy can not be used as the major target factor, because the run of the democratic system depends on its bureaucrat, system implementation and administration process. Although the democratic system has been used by almost every country in the world, it does not automatically guarantee people's prosperity. Abraham Lincoln's concept of democracy; from the people, by the people, for the people, is actually a 'target between' a combination of countries' ideology and the interests of the political map oriented to the interests of public welfare.
\end{abstract}

Keywords: democracy, politics democracy, and welfare

Demokrasi adalah satu kata yang menarik banyak perhatian publik. Secara umum publik menilai bahwa standard hidup yang lebih baik tercapai ketika nilai-nilai demokrasi dapat diterapkan dengan baik. Publik akhirnya dapat melihat dan merasakan penerapan nilai-nilai demokrasi di negara-negara barat pada satu sisi, dan kemudian pada sisi lain ikut menikmati kesejahteraan hidup yang relatif merata di negara barat itu. Dengan kata lain, negara-negara barat menerapkan nilai-nilai demokrasi, sebut saja negara-negara yang termasuk dalam kelompok Overseas Economic Countries Development (OECD), sehingga negara-negara tersebut dapat mewujudkan kesejahteraan hidup yang lebih baik (George, 1998).

Namun demikian penilaian tentang demokrasi pada akhirnya menjadi bias, ketika penerapan demokrasi di sebuah negara tidak terlalu berdampak lebih baik bagi kesejahteraan ekonomi rakyat, seperti di India.Meskipun India dikenal sebagai negara yang menerapkan nilai- nilai demokrasi, namun kesejahteraan hidup di India relatif tidak merata. Paham demokrasi di India, ternyata belum dapat mewujudkan kesejahteraan hidup yang lebih baik. Kemiskinan di India masih tergolong sebagai masalah utama. Pemahaman demokrasi sebagai nilai-nilai yang universal dan telah banyak didiskusikan oleh berbagai kalangan, mulai dari praktisi politik sampai para akademisi, belum memberikan dampak kesejahteraan yang signifikan.

Demokrasi merupakan pilihan berpolitik suatu negara, dengan prinsip-prinsip kebebasan, persamaan dan keberadabannya, yang meyakinkan setiap penganutnya akan mencapai tatanan masyarakat berkeadilan sesuai cita cita konstitusi. Namun fakta tidaklah demikian, selain sebagai fakta ketidak-sinergisan penerapan demokrasi di India, di Indonesi pun juga demikian. Lebih dari satu dasawarsa proses berdemokrasi di Indonesia berjalan meninggalkan catatan sejarah kemiskinan yang masih cukup tinggi, sebagaimana statistik berikut: 
132 | Moh. Zaini, Kebijakan Pemberlakuan Politik Demokrasi ...

Statistik Kemiskinan dan Ketidaksetaraan di Indonesia

\begin{tabular}{|lccccccccc|} 
& 2006 & 2007 & 2008 & 2009 & $\mathbf{2 0 1 0}$ & $\mathbf{2 0 1 1}$ & $\mathbf{2 0 1 2}$ & $\mathbf{2 0 1 3}$ & $\mathbf{2 0 1 4}$ \\
\hline $\begin{array}{l}\text { Kemiskinan Relatif } \\
\text { (\% dari populasi) }\end{array}$ & 17.8 & 16.6 & 15.4 & 14.2 & 13.3 & 12.5 & 11.7 & 11.5 & 11.0 \\
\hline $\begin{array}{l}\text { Kemiskinan Absolut } \\
\text { (dalam jutaan) }\end{array}$ & 39 & 37 & 35 & 33 & 31 & 30 & 29 & 29 & 28 \\
\hline $\begin{array}{l}\text { Koefisien Gini/ } \\
\text { Rasio Gini }\end{array}$ & - & 0.35 & 0.35 & 0.37 & 0.38 & 0.41 & 0.41 & 0.41 & - \\
\hline
\end{tabular}

Sumber: Bank Dunia dan Badan Pusat Statistik (BPS), dikutip dari www.indonesia-investments.com, tanggal 3 Pebruari 2016

Tabel di atas menunjukkan penurunan kemiskinan nasional terjadi secara perlahan. Namun demikian, standar dan persyaratan yang digunakan oleh pemerintah dalam mendefinisikan garis kemiskinan tidaklah ketat, sehingga terlihat gambaran yang lebih kondusif dari fakta yang ada. Tahun 2014 pemerintah Indonesia menggunakan definisi garis kemiskinan (per kapita - per bulan) Rp. 312,328. Jumlah tersebut sama dengan USD \$25. Dengan demikian berarti standar hidup yang dipatok sangat rendah dibanding dengan definisi kemiskinan di negara-negara lain.

Namun jika menggunakan definisi garis kemiskinan World Bank, yang mengategorikan persentase penduduk Indonesia dengan penghasilan di bawah USD $\$ 1.25$ per hari sebagaimana yang hidup di bawah garis kemiskinan, tentu persentase tabel tersebut terlihat kurang akurat karena persentasenya seperti ditinggikan beberapa persen.

Menurut Bank Dunia, jumlah penduduk Indonesia -yang berpenghasilan kurang dari USD \$2 per hari mencapai angka 50.6 persen dari populasi penduduk tahun 2009. Hal ini menggambarkan bahwa mayoritas penduduk Indonesia hidup hampir di bawah garis kemiskinan. Laporan terbaru di media di Indonesia menyatakan bahwa sekitar $1 / 4$ jumlah penduduk Indonesia (sekitar 60 juta jiwa) hidup sedikit di atas garis kemiskinan.

Gambaran di atas tentu sangat bertentangan dengan tujuan penyelenggaraan demokrasi yang terus membaik. Hal ini dibuktikan dengan Indeks Demokrasi di tahun 2011 yang mencapai angka 67,30. Menurut Larry Diamond, yang mengkomparasikan kualitas demokrasi Indonesia dengan negara-negara Asia Selatan, menunjukan kematangan demokrasi di Indo- nesia meningkat secara lebih baik (Laporan Riset:Indeks Demokrasi Asia, 2011:15).

Arus paradoksal pemikiran ini sebenarnya menghendaki perbaikan dan peningkatan kualitas berdemokrasi di tingkat lokal. Sejak tahun 1970an telah terbangun kesepakatan internasional untuk menjadikan pemerintahan yang desentralistik dan demokratis di tingkat lokal sebagai sebuah komitmen global. Komitmen tersebut menjadi diskursus serius para intelektualis di kancah internasional. Pemicunya adalah tumbangnya Uni Soviet bersama ideologinya (fasisme-komunisme), sehingga proses berdemokrasi diyakini sebagai arus global yang serentak menuju kesejahteraan dan kemajuan bagi negara-negara di seluruh dunia.

Demokrasi merupkan sebuah kerja kultural, sosial, dan politik -yang tidak hanya berbicara tentang membangun pranata politik seperti dewan perwakilan atau pemilu, tetapi demokrasi secara utama juga berbicara tentang perkara membangun sikap mental, spirit, yang merupakan core values dari demokrasi itu sendiri seperti toleransi, kesamaan, dan kebebasan. Karena itulah demokrasi hadir juga sebagai kebutuhan budaya, sosial, dan politik (Denny, 2006:xi).

Keberanian bangsa Indonesia untuk memilih jalan demokrasi sebagai solusi dari keberagaman yang melekat sejak republik ini lahir ternyata merupakan langkah yang tepat. Seperti yang dinyatakan Zaenal, (2008:1); walaupun terjal dan penuh liku, demokrasi yang memberi ruang yang luas kepada aspirasi semua kelompok, mampu meminimalisir absolutisme kekuasaan. Kini dapat dilihat bahwa era otoritarianisme tinggal sejarah, digantikan pemerintahan demokratis pilihan rakyat secara langsung. Namun demikian demokrasi 
bukanlah warisan, melainkan sebuah proses pendidikan yang bersifat alami, memerlukan komitmen, konsistensi, dan kesungguhan dalam 'pembelajaran'. Kesungguhan untuk membangun demokrasi yang sehat, bukan hanya sekedar demokrasi prosedural.

Namun penerapan demokrasi di Indonesia, Ginandjar (2008:1-2), menyatakan bahwa demokrasi yang ada pada negara, melalui kebijakan otonomi daerah, kebebasan pers, kebebasan berserikat, meningkatnya peran parlemen, berlangsungnya pemilihan umum yang bebas, dan pemilihan presiden dan wakil presiden secara langsung belum ada dampak yang terlihat jelas bagi masyarakat. Tingginya angka penduduk miskin dan pengangguran, rendahnya taraf pendidikan dan kesehatan merupakan salah satu cerminan kondisi sosial-ekonomi bangsa kita. Berbagai masalah ini diperparah dengan merajalelanya korupsi dan penyalahgunaan wewenang, merosotnya karakter dan harga diri bangsa, merebaknya pornografi dan siaran televisi yang merusak moral bangsa, yang menjadikan generasi muda Indonesia manusiamanusia konsumtif, berbudaya instan, dan ekshibisionis, tanpa idealisme, melemahnya nasionalisme dan patriotisme, sehingga muncul pertanyaan adakah dampak pemberlakuan politik demokrasi terhadap kesejahteraan sosial?

Demokrasi adalah faham -yang bentuk pemerintahannya dan cara hidup yang tidak terlalu ideal, tidak terlalu buruk, tetapi cocok dengan kehidupan masyarakat, dan dapat dinikmati oleh masyarakat. Demokrasi membutuhkan sebuah prospek kedepan, yang didukung oleh faktor ekonomi, sosial, baik secara eksternal, dan juga kultural. Demokrasi merupakan political choice dengan prinsip-prinsip kebebasan (freedom), persamaan (equation) dan peradabannya diyakini mampu mengantarkan masyarakat menuju keadilan sosial sesuai cita-cita konstitusi.

\section{THE REAL DEMOCRACY}

Demokrasi adalah sebuah sistem nilai universal -yang tidak hanya mencakup sistem nilai konstruksi penyelenggaran pemerintahan dalam sebuah negara, tetapi mencakup universalitas nilai-nilai kemanusiaan. Dalam hal ini, demokrasi dalam konteks Indonesia, didasarkan pada ideologi Pancasila sila ke-4: kerakyatan yang dipimpin oleh hikmat kebijaksanaan dalam permusyawaratan perwakilan. Namun demikian dasar ideologi ini dibutuhkan realisasi strategis -yang dalam hal ini Moh. Hatta menyampaikan pandanganya tentaang praktik-praktik strategis demokrasi di masa lalu.Terdapat lima unsur demokrasi asli Indonesia: Pertama adalah mufakat, karena tanah merupakan milik bersama, maka segala keputusan tentangnya memerlukan persetujuan bersama, yaitu kesepakatan.Kedua adalah rapat, keperluan untuk memufakatkan sesuatu keputusan menumbuhkan institusi rapat sebagai forum musyawarah. Ketiga adalah gotong-royong, yang merupakan kelanjutan dari hak milik bersama atas tanah. Keempat adalah hak protes bersama, yaitu hak untuk menolak atau memprotes peraturan raja atau penguasa yang dirasa tidak adil. Kelima adalah hak untuk menyingkir dari kekuasaan penguasa bilamana rakyat merasa tidak senang lagi, diam di bawah kekuasaan penguasa (Cosmas, 2007:74).

Dalam teori demokratisasi dikenal dua tahap, yaitu tahap transisi dan tahap konsolidasi. Transisi seperti dikatakan oleh O'Donnell dan Schmitter (1991) adalah masa antara dua rezim politik. Transisi demokrasi dimulai sejak bergulirnya proses desolusi (tumbangnya) sebuah rezim otoriter pada ujung yang satu dan ditegakkannya rezim demokrasi pada ujung yang lainnya. Pada tahapan ini penekanan ada pada penegakan demokrasi secara prosedural yakni berfungsinya berbagai institusi-institusi politik secara demokratis.

Namun untuk benar-benar menjadi negara demokrasi, haruslah dilalui tahap konsolidasi yang menurut beberapa literatur merupakan konsep yang tidak kalah sulitnya dibanding proses transisi. Bahkan banyak negara yang jatuh kembali ke rezim otoriter karena gagal menyelesaikan proses konsolidasi demokrasi. Konsolidasi demokrasi berarti bahwa demokrasi bukan hanya telah tegak sebagai sebuah sistem politik tetapi juga telah membudaya di kalangan masyarakat. Bahkan betapapun besarnya tantangan dan kesulitan yang dihadapi masyarakat tidak akan berpaling dari demokrasi ke sistem politik lain.

Keterkaitan antara demokrasi dengan kesejahteraan masyarakat melalui ekonomi pasar telah sedemikian berkembang dan teruji selama lebih dari dua ratus tahun di negara-negara Barat. Sedemikian erat keterkaitan kedua hal tersebut sehingga dalam perkembangannya peningkatan kesejahteraan rakyat juga telah 
dijadikan barometer berlangsung tidaknya proses demokrasi. Artinya, proses demokrasi belum dikatakan baik jika tidak dapat melahirkan peningkatan kesejahteraan. Amartya Sen, seorang ekonom penerima nobel tahun 2001, melukiskan demokrasi sebagai koridor utama dalam memahami persoalan kemiskinan. Pandangan-pandangannya telah menginspirasi banyak pemikiran tentang bagaimana memahami miskin (buruk) nya demokrasi yang melahirkan ketidakadilan -yang berdampak pada terbatasnya kesempatan dan suara masyarakat miskin dalam menyampaikan aspirasinya, serta berakibat terdilusinya sasaran banyak programprogram pembangunan ekonomi (Ginandjar, 2008:3-5).

Di dalam pandangannya, Amartya Sen (1999), mengupas tentang konsep nilai-nilai demokrasi yang secara ideal bisa diterapkan oleh bangsa manapun di muka bumi ini. Konsep ini juga bisa dijumpai di bangsa manapun yang telah mempunyai tradisi demokrasi. Konsep ini mencakup tiga pandangan utama, yaitu:

\section{Intrinsic importance in human life}

Pentingnya hakikat kehidupan manusia (intrinsic importance in human life). Konsep ini dilandasi oleh pandangan bahwa melalui demokrasi, warga negara dapat menjalankan partisipasi politik dan mempunyai kebebasan politik dalam statusnya sebagai kehidupan kemanusiaan seutuhnya. Status sebagai kehidupan kemanusiaan (human life) yang bebas sesungguhnya merupakan nilai-nilai yang diakui secara universal oleh setiap bangsa dan ajaran agama apapun di dunia.

\section{Instrumental role in generating political incentives}

Peran pembantu dalam menggerakkan dorongan politik (instrumental role in generating political incentives). Konsep ini dilandasi oleh pandangan bahwa melalui demokrasi, pemerintah akan selalu bertanggung-jawab dan terbuka dalam menjalankan kewajiban pemerintahannya. Kewajiban pemerintahan adalah peran yang muncul sebagai akibat adanya status kehidupan kemanusiaan yang bebas. Pemerintah berkewajiban menjamin status ini dan melindunginya dari ancaman penindasan terhadap kehidupan kemanusiaan. Ancaman terhadap demokrasi adalah ancaman terhadap kelangsungan kehidupan kemanusiaan.

\section{Constructive function in the formulation of values}

Fungsi pembangun dalam pembentukan nilai-nilai (constructive function in the formulation of values). Konsep ini dilandasi oleh pandangan bahwa melalui demokrasi, setiap bangsa dapat membentuk nilai-nilai dan membangun kesepahaman tentang kebutuhan, hak, dan kewajiban. Kesepahaman ini perlu dibangun oleh suatu bangsa, jika suatu bangsa ingin mewujudkan demokrasi di negara nya.

Demokrasi sebagai nilai universal menurut Sen adalah demokrasi yang memberikan kebebasan kepada setiap manusia untuk menentukan pilihannya sendiri. Pilihan manusia yang sangat beragam, keberagaman ini ialah universalitas itu sendiri. Karena secara universal manusia mempunyai kebutuhan yang tidak selalu sama. Agar kebebasan ini tidak melampaui batas, maka kebebasan ini dibatasi oleh adanya hak dan kewajiban yang berlaku merata bagi setiap manusia atau warga negara.

\section{DEMOKRASI PRAKTIS DI INDONESIA}

Penyebaran demokrasi adalah fenomena yang relatif baru. Implikasinya tampaknya adalah bahwa demokrasi memerlukan kondisikondisi yang dihasilkan oleh masyarakatindustri modern untuk menciptakan demokrasi.

Prakondisi pertama adalah modernisasi dan kesejahteraan akan selalu disertai dengan sejumlah faktor yang kondusif bagi demokrasi: meningkatnya tingkat melek huruf dan tingkat pendidikan, urbanisasi, danpembangunanmedia massa. Sejalan dengan hal tersebut, kesejahteraan juga akan memfasilitasi resourcesneeded untuk meredakan ketegangan yang ditimbulkan oleh konflik politik (Huntington, 1984:199) Banyak analisis empiris yang diilhami oleh hipotesisi Lipset yang cenderung mendukung perrnyataan tersebut. Jadi, pada tahun 1971, Robert Dahl menyebutkan sebagai "hampir di luar perdebatan" bahwa semakin tinggi tingkat sosial ekonomi suatu negara, akan semakin mungkin bagi negara tersebut untuk menjadi demokratis (Robert A. Dahl, 1971:65).

Prakondisi kedua yaitu sistem nilai dan keyakinan yang menjelaskan konteks dan makna dari tindakan politik. Dan ini seringkali dikemukakan dalam upaya menentukan faktorfaktor yang mendukung demokrasi mengenai budaya politik. 
Prakondisi ketiga yang menguntungkan bagi demokrasi adalah struktur sosial masyarakat, yaitu kelas dan kelompok tertentu dalam masyarakat. Dalam kajian historisnya mengenai akar demokrasi dan kediktatoran, Barrington Moore menyimpulkan bahwa "sebuah kelas penduduk kota yang besar dan independen telah menjadi elemen yang sangat diperlukan dalam pengembangan demokrasi parlementer. Tidak ada borjuis tidak ada parlementer. Tidak ada borjuis tidak ada demokrasi (Barrington,1966:418).

Prakondisi terakhir disini adalah faktorfaktor eksternal, yaitu faktor ekonomi, politik, ideologi, dan elemen-elemen lain yang merupakan konteks internasional dari proses yang terjadi di suatu negara. Tidak ada kesimpulan langsung mengenai efek faktor eksternal terhadap demokrasi. Oleh karena itu Huntington (1984:206), mengatakan: Negara-negara berkembang di dunia ketiga adalah negara-negara yang paling rentan terhadap pengaruh eksternal, terutama oleh negara-negara barat. Adalah hal yang lumrah di kalangan teoretisi modernisasi untuk menganggap bahwa pengaruh tersebut bermanfaat untuk mengembangkan demokrasi. Teoretisi Dependensi menarik kesimpulan yang bertolak belakang: Ketimpangan dan distorsi ekonomi dan masyarakat Dunia Ketiga, yang disebabkan oleh ketergantungannya dalam sistem ekonomi dunia, membuat demokrasi sangat sulit diwujudkan.

Keempat prakondisi yang dibutuhkan untuk demokrasi telah diketahui. Tentu saja masih dimungkinkan untuk menyebut sejumlah prakondisi lainnya. Pengakuan terhadap pentingnya pilihan-pilihan yang diambil oleh aktor-aktor politik tidak berarti bahwa pencarian prakondisi tersebut tidak berguna sama sekali. Aktor tidak dapat membuat suatu jenis pilihan dalam suatu situasi yang given. Dalam arti ada batasan-batasan struktur-struktur prakondisi yang merupakan hasil dari pembangunan nasional pada waktu sebelumnya. Oleh karena itu, harus ada upaya yang menghubungkan tingkat saling mempengaruhi diantara prakondisi ekonomi, sosial, budaya, dan lain-lainnya, yang terbentuk pada periode sebelumnya dan keputusan yang diambil oleh aktor politik.

Prakondisi tersebut tidak dapat meramalkan apakah aktor politik akan menghasilkan perilaku demokrasi atau tidak, namun dapat menghasilkan beberapa informasi mengenai jenis hasil (out-come) yang diharapkan dari para aktor. Walaupun negara-negara yang sangat miskin dengan prakondisi ekonomi, sosial yang berlawanan mungkin bergerak menuju demokrasi sebagaimana terlihat di beberapa negara di Afrika saat ini. Oleh karena itu, harapan yang dapat dibangun, bahwa hasil yang dimaksud lebih sedikit dibandingkan di negara-negara dengan prakondisi yang lebih menguntungkan. Dalam arti bahwa demokrasi yang muncul di bawah kondisi yang berlawanan tersebut adalah demokrasi yang sangat tidak stabil, lemah,dan rentan.

Terdapat nilai-nilai local democracy yang cukup sukses membawa suatu bangsa ke taraf kesejahteraan yang lebih baik. Sebagai sebuah perbandingan, misalnya Cina, sejak masa Pemerintahan Deng Xiao Ping mulai membuka diri terhadap nilai-nilai demokrasi dengan muatan lokal, di antaranya bersedia menjalankan kebijakan Cina dengan dua sistem. Propinsi Guangzu dan Special Administrative Region Hong Kong adalah contoh beberapa provinsi di Cina yang menerapkan nilai-nilai demokrasi. Warga negara di kedua wilayah itu diberikan kebebasan berinvestasi dan melakukan akumulasi kapital di wilayah itu. Saat ini Cina merupakan negara yang makmur dibandingkan dengan negara-negara komunisme lainnya.

Tetapi banyak pula negara berpaham demokrasi yang tidak sukses. Suatu negara menerapkan paham demokrasi, tapi ternyata malah 'berantakan'. Ketika gerbang demokrasi dibuka, maka sebaliknya kekacauan politik terjadidiberbagailevel pemerintahan, kerusuhan horizontal antarwarga negara, perang saudara, kerusuhan etnis, dan lain-lain. Kekacauan ini akhirnya menyebabkan terganggunya atau bahkan terhentinya kegiatan ekonomi. Contoh untuk kasus ini banyak ditemui di beberapa negara di Amerika Latin seperti Argentina, Afrika Timur seperti Mozambik, dan di Asia seperti Indonesia dan Timor Timur.

Demokrasi merupakan bagian dari proses reformasi politik yang sekarang sedang dijalani oleh bangsa Indonesia. Jatuhnya rezim otoritarian Orde Baru yang berjubah demokrasi Pancasila membuka pintu bagi episode politik baru di Indonesia. Dinamika politik transisi yang penuh kejutan di Indonesia ditandai oleh gambaran masa pancaroba dengan pergiliran dialektis antara konflik dan konsensus, serta antara kompetisi dan kongsi. Demokratisasi 
menghajatkan peremajaan struktur politik modern disamping penyiapan basis kebudayaan yang matang. Prosedur dan aktor demokrasi seperti partai politik, elite politik, masyarakat sipil, koalisi, oposisi, dan pemilu sebagai instrument demokrasi bergerak pada posisinya.

Ketika elit memanfaatkan demokrasi sebagai alatuntukmengamankan pemilihan presiden, merupakan teori yang banyak berlaku di negara berkembang, tidak terkecuali negara-negara Asia Tenggara, seperti Indonesia, Filipina, Malaysia, dan Singapura. Przeworski (1998), menyatakan bahwa kelompok elit akan mendukung demokrasi jika kepentingan tersebut diyakini akan dapat terwujud dalam kondisi yang lebih demokratis. Dukungan elit pada demokratisasi seringkali didasarkan kepada kepentingan pribadi.

Sedangkan teori yang sering dijadikan dasar, bahwa demokratisasi dilakukan melalui modernisasi, termasuk di antaranya pengembangan lembaga-lembaga politik demokrasi institution's building. Huntington, (1991) mengemukakan bahwa tanpa kesiapan kelembagaan politik, maka partisipsi di dalam demokrasi hanya akan menghasilkan pembusukan politik. Tesis ini yang dibawanya ketika memberikan nasihat yang kemudian diikuti oleh negara-negara berkembang, yaitu membangun kelembagaan dulu, kemudian partisipasi. Pemahaman teoritisnya sangat sederhana. Pertama, kekang partisipasi, biarkan kekuasaan yang otoritarian berjalan dengan tujuan menyiapkan lembaga politik demokratis dan menyiapkan masyarakat. Kedua, lepas perlahan-lahan, dan Ketiga, demokrasi akan berjalan dengan sendirinya.

Kesiapan kelembagaan dicerminkan dari kesiapan untuk melakukan proses demokrasi, mulai dari input-pengolahan-output, kesiapan masyarakat dicerminkan dari kesiapan masyarakat untuk mampu berperan positif dalam demokrasi karena sudah tercapai tingkat pendidikan yang memadai dan kesejahteraan yang juga memadai. Tetapi pada kenyataannya, transisi yang elitis tersebut tidak pernah berjalan sampai ke tujuan. Proses transisi berhenti karena demokrasi akan merugikan kekuasaan yang otoriter sampai akhirnya ada sebuah peristiwa, khususnya yang merusak prestasi pembangunan yang akhirnya meruntuhkan rezim otoritarian dan diharapkan akan menuju kepada demokrasi. Salah satu proses perusakan tersebut adalah krisis ekonomi yang melanda negara-negara berkembang.

Dari sini kemudian berkembang proposisi bahwa pada tahun 1990an terjadi transisi dari demokrasi terbatas, yaitu di mana sistem politiknya memiliki elemen-elemn demokrasi namun memiliki keterbatasan pada kompetisi, partisipasi, dan kebebasan, menuju demokrasi yang lebih liberal. Transisi yang terdekat dapat dilihat adalah kasus Indonesia. Setelah Soeakrno memproklamirkan Demokrasi Terpimpin dan kemudian menjadikan dirinya sebagai Presiden Seumur Hidup, maka menurut kriteria demokrasi, Indonesia bergerak menjadi negara yang non-demokratis (otoritarian). Transisi dari Soekarno ke Soeharto adalah transisi dari otoritarianisme ke demokrasi melalui jalan modernisasi (pembangunan).

Pada era Soeharto instrumen-instrumen demokrasi dibentuk dan dijalankan dengan pola yang tetap, misalnya pemilihan umum mulai dapat dilakukan secara rutin lima tahunan. Lembaga legislatif, yudikatif, eksekutif dikembangkan.Partaipolitikberkembang. Media massa tumbuh. Namun, semua dalam koridor yang cukup sempit, terutama dalam tiga hal yang dijadikan kriteria demokrasi kompetisi (karena negara memonopoli), partisipasi (cenderung mobilisasi), dan kebebasan (informasi berjalan relatif satu arah negara ke rakyat) (Sorensen, 1998).

Demokrasi terbatas menemui jalan buntu ketika pembangunan berhadapan dengan kegagalan. Pembangunan yang ditunjukkan oleh pertumbuhan ekonomi yang tinggi memang menjadi penyeimbang bagi rezim demoriter (demokrasi-otoriter) dengan jaminan kesejahteraan yang diberikan, maka rakyat tidak mempermasalahkan apakah negara itu menjadi demokratis atau tidak. Singapura, Malaysia, dan Cina barangkali dapat dijadikan contohnya.

Proses demokrasi di Indonesia, bermakna bahwa bangsa Indonesia membutuhkan secara segera gerakan besar dan konsisten untuk menjaga jalannya demokratisasi (Anas, 2004). Dalam menapaki demokrasi, harus dihindari munculnya antitesis terhadap demokrasi itu sendiri, yaitu munculnya oligarkhi yang justru merintangi tumbuhnya kesejahteraan sosial. Antisipasi terhadap munculnya peristiwa yang mengatasnamakan demokrasi tetapi justru merintangi tumbuhnya kesejahteraan sosial harus segera dihindarkan. 
Roda demokrasi harus dikawal, agar dalam proses transisi demokrasi ini tidak muncul pergeseran lokasi pelaku (Teori Bandit) (Didik, 2008). Di masa otoriter, para bandit adalah kekuasaan pemerintah dan swasta yang melakukan korupsi dan kolusi, sehingga menghasilkan kesenjangan ekonomi antara kelompok kecil dengan masyarakat bawah yang tingkat kesejahteraannya masih rendah. Sementara pada masa transisi demokrasi, peran 'bandit' telah digantikan oleh anggota parlemen dan unsur birokrasi yang berkolusi dengan anggota parlemen sebagai akibat dari kebijakan penganggaran yang belum stabil. Teori ini sesuai dengan gejala yang sekarang terjadi di Indonesia dan merupakan fenomena yang sumbernya dapat menghancurkan cita-cita demokrasi itu sendiri, yaitu memberikan pilihan kepada rakyat untuk menentukan nasib sendiri.

Dalam masa transisi, bangsa Indonesia harus mempersiapkan prakondisi menuju kesejahteraan sosial, sebuah prakondisi yang dapat menjadi landasan penyelenggaraan negara kesejahteraan. Perlu mempersiapkan sistem kenegaraan Republik Indonesia yang merupakan satu entitas yang saling terkait, yaitu:1. Sistem administrasi negara, 2. sistem administrasi pemerintahan, 3. sistem pemerintahan daerah, 4 . sistem peradilan, 5 . sistem pengawasan dan pemeriksaan pembangunan, 5. sistem politik, 6. sistem pembangunan, dan 7 . sistem perencanaan dan keuangan negara. Dalam hal ini akuntabilitas sistem yang bergerak melalui stiap unsur-unsur kelembagaan diharapkan dapat saling menunjukkan keterkaitan, sehingga pencapaian sebuah tujuan besar entitas kesejahteraan dapat diwujudkan.

Meskipun demikian, Randy (2009:191228), mengatakan bahwa keterkaitan antara sistem-sistem tersebut berdasarkan cakupannya merupakan tata sistem kenegaraan yang sangat kompleks, karena meliputi seluruh aspek kehidupan bernegara sebagaimana yang diamanahkan oleh UUD 1945. Berkenaan dengan kasus-kasus yang terjadi Indonesia, tentu dibutuhkan penerapan nilai-nilai demokrasi sebagai nilai-nilai universal ideal yang dimasukkan ke dalam kehidupan berbangsa dan bernegara, dengan memperhatikan beberapa tahapan. Masing-masing tahapan membutuhkan waktu untuk mencapainya, karena demokrasi bukan suatu tujuan akhir.

Adapun tahapan-tahapan tersebut, yaitu: Pertama, tahap pra-kondisi. Pada bagian ini, suatu bangsa menetapkan asumsi dasar tentang perlunya berdemokrasi. Asumsi dasar tersebut dibangun dengan menjawab beberapa pertanyaan pokok berikut ini. Mengapa diperlukan demokrasi? Apakahdemokrasiadalahsatu-satunyajalan?Yang manakah demokrasi pilihan kita? Bagaimanakah cara kita menerapkan demokrasi? Pertanyaan dan jawaban seputar demokrasi harus menjadi wacana publik. Masyarakat diharapkan mampu belajar tentang konsep demokrasi sebelum menerapkan demokrasi. Dalam hal ini, konflik horizontal dan gesekan (friction) antar kelompok masyarakat akan segera mencuat ke permukaan oleh karena ketidaktuntasan memahami konsepsi demokrasi. Sedangkan jaringan organisasi non-pemerintah pro-demokrasi dalam hal ini bertindak sebagai mediator.

Kedua, tahap transisi menuju demokrasi; bahwasuatubangsa membuatkristalisasi tentang model demokrasi. Sebagian besar warga negara sudah mengalami perubahan sikap dari tidak tahu tentang demokrasi menjadi tahu tentang demokrasi. Bentukdemokrasi yang digambarkan menjadi bagian dari cara berpikirnya. Secara informal demokrasi dipahami oleh sebagian besar warga negara, dan pemerintah diharapkan memulai mempersiapkan segala komponen dan sistemnya, bekerja sama dengan jaringan organisasi non-pemerintah pro demokrasi, sehingga mendapatkan dukungan, serta mempersiapkan proses transisi menuju demokrasi secara damai. Cara-cara damai sangat ditekankan dalam proses transisi ini. Untuk barada dalam keadaan damai ini, semua pihak harus mengedepankan toleransi.

Ketiga, tahap pembakuan nilai-nilai demokrasi. Demokrasi secara formal diberlakukan, ditandai dengan terbentuknya pemerintahan baru yang dipilih secara langsung oleh rakyat (atau dipilih oleh parlemen yang dipilih oleh rakyat). Pemerintahan baru segera bekerja untuk membangun landasan formal bagi terpeliharanya demokrasi. Pemerintah menerapkan ukuran-ukuran tentang kebutuhan, hak, dan kewajiban warga negara. Parlemen memutuskan secara terbuka peraturan-peraturan dasar tentang hak dan kewajiban warga negara. Pemerintah mempersiapkan perangkat-perangkat penyelenggaraan demokrasi, antara lain yang utama adalah penyiapan institusi hukum dan perangkat penegakan hukum. Lembaga hukum menjadi penting ketika demokrasi berjalan di alam demokrasi. 
138 | Moh. Zaini, Kebijakan Pemberlakuan Politik Demokrasi ...

Keempat, tahap penegakan hukum. Pada tahap ini penegakan hukum merupakan prioritas dan sekaligus merupakan pilar utama demokrasi. Pemerintah bersama jaringan organisasi non-pemerintah bekerja sama, membantu masyarakat (warga negara) untuk memenuhi kebutuhan hidupnya. Pemerintah bersama jaringan organisasi non-pemerintah secara pro-aktif bekerja mendampingi masyarakat pemenuhan hak dan menunaikan kewajibannya secara seimbang.

Kelima, tahap kesejahteraan sosial. Setiap anggota masyarakat (warga negara) sadar akan hak dan kewajibannya. Demokrasi sudah menjadi tradisi masyarakat. Demokrasi dilaksanakan dalam koridor yang tertuang dalam sistem hukum. Di dalam sistem hukum itulah diatur hak dan kewajiban setiap warga negara secara seimbang. Kegiatan ekonomi dan politik berjalan dalam koridor tersebut. Setiap warga negara bebas menetukan pilihannya untuk melakukan kegiatan ekonomi dan politik. Namun ketika sudah menentukan pilihahnnya, maka sebagai konsekuensinya dengan sendirinya akan terikat dengan suatu kewajiban yang harus dijalankannya. Suatu kewajiban yang menjadikan setiap warga negara secara relatif akan memperoleh peluang yang sama dalam menikmati kesejahteraan. Dengan demikian, tahap ini merupakan tahap yang ditandai dengan kesejahteraan sosial yang semakin meluas. Inilah sesungguhnya hakikat demokrasi -yang mengantarkan suatu bangsa untuk menikmati kesejahteraan sosial.

Berdasarkan UUD 1945 dalam sistem kenegaraan Republik Indonesia, sistem administrasi memiliki cakupan yang sangat luas. Karena merupakan interaksi kelembagaan antara sistem-sistem administrasi pemerintahan, pemerintahan daerah, peradilan, pengawasan dan pemeriksaan pembangunan, politik, pembangunan, dan perencanaan dan keuangan negara. Perlu disepakatinya indikator pembangunan yang dapat mengindikasikan pencapaian demokrasi Indonesia. Siklus hidup manusia merupakan dasar utama pemilihan indikator pembangunan. Indikator pembangunan yang disepakati merupakan dampak penerapan demokrasi itu sendiri. Indikator untuk mengukur dampak penerapan demokrasi antara lain adalah indikator pembangunan manusia yang tertuang dalam Millenium Development Goals(Wrihatnolo, 2007).

\section{CIVIL SOCIETY DAN DEMOKRASI}

Memperbincangkan civil society berarti mengasumsikan hubungan antara negara bersama rakyat terjalin secara seimbang (Adam dalam Adi Suryadi, 1999:30). Tetapi dalam kontek ini perlu ditinjau kembali, karena terdapat posisi yang timpang antara negara dan rakyat. Sementara yang diinginkan masyarakat adalah hubungan setara diantara keduanya. Selama masih ada ketimpangan hubungan diantara keduanya, maka selama itu pula konsep civil society menarik diperbincangkan untuk mencari tatanan dan pola relasi yang ideal.

Bangsa Indonesia saat ini berada pada fase reformasi, membangun demokrasi -yang tidak dapat dilepaskan dari reformasi. Tetapi demokrasi tidak dapat berlangsung penyelenggaraannya bila civil society lemah dalam berhadapan dengan negara. Dari point ini, terdapat sebuah tesis yang mengatakan bahwa demokrasi akan berlangsung jika civil society kuat dalam berhadapan dengan negara. Bila tesis ini dibalik, selanjutnya dapat dikatakan bahwa demokrasi adalah penyangga civil society. Jika demokrasi berjalan, maka civil society akan kuat pada saat berhadapan dengan negara. Bertolak dari tesis tersebut dapat disimpulkan bahwa demokratisasi dipahami sebagai proses pemberdayaan civil society, sebagai sebuah teks yang terbuka, karena civil society tidak dapat dianalisis secara tepat maka civil society disamakan dengan masyarakat madani (Madjid, 21-22 Agustus 1996).

Dengan menempatkan civil society dalam frame demokrasi maka pengertian civil society dapat dipahami sebagai penegakan nilai-nilai demokrasi. Dengan demikian agenda untuk membangun civil society sudah barang tentu termasuk menciptakan ruang gerak bagi komponen masyarakat untuk melakukan perubahan-perubahan hidup guna mencapai kesejahteraan tanpa ada penindasan, baik fisik maupun sistemik. Tanpa adanya pengingkaran keberadaan suatu masyarakat ataupun kelompok, kehidupan berjalan di atas prinsip penghormatan satu terhadap yang lainnya.

Dengan demikian, Civil society adalah rumah di mana berbagai macam perserikatan, kelompok, jama'ah, pengajian, partai, ormas bergabung untuk menjadi perisai antara negara dan warga negara. Pengalaman negara-negara di Amerika Latin, Eropa Selatan dan Timur, 
dapat diambil hikmahnya bahwa ternyata civil society berjasa dalam menghalangi rancangan kekuasaan otoriter dan menentang pemerintahan yang sewenang-wenang. Walaupun demikian, civilsociety tidak menumbangkan pemerintahan karenacivil society merupakan perisai dalam hubungan negara dengan warga negara, dan lebih merupakan penerima manfaat (beneficiary) daripada sebuah kekuatan penghancur. Civil society lah yang diuntungkan dari berkembangnya asosiasi, kelompok, jama'ah, ormas dan sebagainya yang semakin mandiri dan tidak bergantung pada negara. Semakin mandiri asosiasi, kelompok, persatuan, dan sebagainya, maka akan semakin kuat, demokratisasi dan budaya civil akan semakin berkembang. Sebaliknya jika asosiasi, keompok, jama'ah, ormas, persatuan, dan yang sejenisnya tidak bisa berkembang dengan baik, tetapi malah justru tenggelam dalam hegemoni negara, maka civil society-lah yang akan rugi. Karena civil society adalah rumah tempat semuanya itu berhimpun.

Civil society bukan sekedar tempat bergabungnya berbagai bentuk asosiasi, tetapi lebih dari itu di dalam diri civil society ada kualitas civility, yang tanpa itu lingkungan hidup sosial akan hanya terdiri dari faksi-faksi, klik-klik, dan serikat-serikat rahasia yang saling menyerang. Civility mengandung makna toleransi, kesediaan pribadi-pribadiuntukmenerimaberbagaimacam pandangan politik dan tingkah laku sosial, juga kesediaan untuk menerima pandangan yang sangat penting bahwa tidak selalu ada jawaban yang benar atas suatu masalah.

Fatalnya, dewasa ini civilitysebagaisebuah mutu, banyak hilang di negara-negara berkembang. Mungkin saja suatu negara menjunjung tinggi kehidupan keserikatan (associationallife) yang aktif, tetapi fakta yang sering ditemuibahwacivilsociety dirongrong oleh kurangnya toleransi politik dan terkekang oleh peraturan pemerintah yang sewenang-wenang. Pada hal elemen penting dari civil society adalah demokrasi. Oleh karena itu, Ernest Gellner menyampaikan pandangannya yang cukup popule, yakni "no civil society, no democracy" (Fukuyama, 1 Oktober 1999:5).Kualitas civil society sangat ditentukan oleh demokrasi. Semakin demokrasi tumbuh subur dan berkembang,maka civil society semakin menguat dan berkualitas.

\section{PERTUMBUHAN DAN DEMOKRASI EKONOMI}

Sistem demokrasi yang terbentuk di Indonesia, sejauh ini masih lebih menonjolkan kepentingan personal dan komunal, ketimbang kepentingan rakyat yang menjadi pemilik kedaulatan, sehingga transisi menuju democratic governance masih belum dapat menghasilkan sebuah pemerintahan yang profesional, efektif, efisien, dan kredibel (Ginandjar, 2008:12). Ditambah lagi dengan adanya fakta, bahwa pemimpin / pejabat yang tidak memiliki kompetensi di bidangnya atau kurang cukup berpengalaman untuk mengambil peran dalam penyelenggaraan negara terutama dalam kondisi ekonomi bangsa yang melemah.

Perkembangan ekonomi yang diharapkan oleh para pendiri Republik ini, tidak dapat terjadi dengan sendirinya. Dalam arti, kemajuan yang diukur melalui membesarnya produksi nasional tidak otomatis menjamin bahwa pertumbuhan tersebut dapat meningkatkan kesejahteraan rakyat secara merata. Masalah utamanya adalah instabilitas dalam kemampuan dan kesempatan untuk memanfaatkan peluang yang ada dalam proses pembangunan. Dengan proses pembangunan yang terus berlanjut, maka akan membuat ketidakseimbangan itu makin membesar -yangmengakibatkan semakin melebarnya jurang kesenjangan.

Oleh karena itu sebagai tawaran solusi untuk mengatasi masalah tersebut adalah melalui pemberdayaan masyarakat. Solusi ini merupakan pengerahan sumber daya untuk mengembangkan potensi ekonomi rakyat, dengan meningkatkan produktivitasnya, sehingga sumber daya manusia maupun sumber daya alam di sekitarnya dapat ditingkatkan produktivitasnya. Dengan demikian, rakyat dan lingkungannya mampu secara partisipatif menghasilkan dan menumbuhkan nilai tambah ekonomis. Rakyat miskin atau yang berada pada posisi belum termanfaatkan secara penuh potensinya akan meningkat bukan hanya pada segi ekonomi, tetapi juga harkat, martabat, rasa percaya diri, dan harga dirinya.

Pemberdayaan masyarakat adalah sebuah konseppembangunanekonomiyangmerangkum nilai-nilai demokrasi. Konsep ini lebih luas dari hanya semata-mata memenuhi kebutuhan dasar (basicneeds) atau menyediakan mekanisme untuk mencegah proses pemiskinan lebih lanjut (safety $n e t)$, yang pemikirannya belakangan ini banyak 
dikembangkan sebagai upaya mencari alternatif terhadap konsep-konsep pertumbuhan di masa yang lalu. Konsep ini berkembang dari upayaupaya yang dilakukan para ahli dan praktisi untuk mencari apa -yangantara lain oleh Friedman (1992) disebut alternativedevelopment, yang menghendaki "inclusive democracy, appropriate economic growth, gender equality and intergenerational equity".

Strategi pembangunan yang bertumpu pada pemihakan dan pemberdayaan dipahami sebagai suatu proses transformasi dalam hubungan sosial, ekonomi, budaya, dan politik masyarakat. Perubahan struktural yang diharapkan adalah proses yang berlangsung secara alamiah, yakni yang menghasilkan harus menikmati. Begitu pula yang menikmati haruslah yang menghasilkan.Dalam upaya tersebut, perlu adanya strategi pemberdayaan masyarakat yakni sebagai berikut:

Pertama adalah memberi peluang agar sektor dan masyarakat modern dapat tetap maju, karena kemajuannya dibutuhkan untuk pembangunan bangsa secara keseluruhan. Di sini termasuk peningkatan efisiensi, produktivitas, dan pengembangan serta penguasaan teknologi, yang amat diperlukan untuk memperkuat daya saing.

Kedua adalah memberdayakan sektor ekonomi dan lapisan rakyat yang miskin dan tertinggal dan hidup di luar atau di pinggiran jalur kehidupan modern. Intinya adalah membantu rakyat agar lebih berdaya sehingga tidak hanya dapat meningkatkan kapasitas dan kemampuannya dengan memanfaatkan potensi yang dimiliki, tetapi juga sekaligus meningkatkan kemampuan ekonomi nasional.

Kedua strategi tersebut tidak dapat terlepas satu dengan yang lainnya, keduanya saling berhubungan. Pola hubungan tersebut dibutuhkan penataan, sehingga menghasilkan suatu struktur ekonomi dan masyarakat yang sinergis menuju ke arah pembangunan ekonomi yang berkesinambungan, merata, dan tumbuh di atas landasan yang kukuh (Ginandjar, 2008). Dalam kerangka pemikiran di atas, dibutuhkan upaya pemberdayaaan masyarakat yang dilakukan melalui tiga hal, yaitu:

Pertama, menciptakan suasana atau iklim yang memungkinkan potensi masyarakat berkembang (enabling). Di sini, titik tolaknya adalah pengenalan bahwa setiap manusia, setiap masyarakat, memiliki potensi yang dapat dikembangkan. Karena tidak ada masyarakat yang sama sekali tanpa daya.Kedua, memperkuat potensi atau daya yang dimiliki oleh masyarakat (empowering). Dalam rangka ini diperlukan langkah-langkah lebih positif selain dari hanya menciptakan iklim dan suasana.Dalam rangka pemberdayaan ini, upaya yang paling pokok adalah peningkatan taraf pendidikan dan derajat kesehatan, serta akses kepada sumbersumber kemajuan ekonomi seperti moda, teknologi, informasi, lapangan kerja, dan pasar. Pemberdayaan ini menyangkut pembangunan prasarana dan sarana dasar baik fisik, seperti irigasi, jalan, listrik, maupun sosial seperti sekolah, dan fasilitas pelayanan kesehatan, yang dapat diakses oleh masyarakat pada lapisan paling bawah serta kesediaan lembaga-lembaga pendanaan, pelatihan, dan pemasaran di pedesaan tempat terkonsentrasinya penduduk yang keberdayaannya amat kurang.

Ketiga, memberdayakan mengandung pula arti melindungi. Dalam proses pemberdayaan, harus dicegah yang lemah menjadi bertambah lemah,keranakurangberdayadalammenghadapi yang kuat. Oleh karena itu, dalam konsep pemberdayaan masyarakat, perlindungan dan pemihakan kepada yang lemah amat mendasar sifatnya. Dalam rangka ini, adanya peraturan perundangan yang jelas dan tegas berpihak pada (affirmative) dan melindungi golongan yang lemah sangat diperlukan.

\section{MENGAKHIRI BUDAYA KORUPSI}

Di penghujung tahun 2005 lalu, Presiden Susilo Bambang Yudhoyono menegaskan bahwa kerja pemberantasan korupsi selama setahun cukup membanggakan. Tak kurang dari 63 Bupati, Walikota, Gubernur, anggota DPR/ DPRD maupun mantan pejabat masa lalu yang diperiksa. Padahal di era sebelumnya, pejabat seakan berdiri di satu dunia, sementara penegakan hukum di dunia lain. SBY juga yakin bahwa langkah tersebut telah mampu mencegah timbulnya korupsi baru di kalangan kekuasaan atau birokrasi.

Menariknya, closingstatement SBY di atas langsung mendapat respon dari Amien Rais (AR) -yang menyoroti tentang penanganan korupsi pada kasus kelas teri. Bahkan menurut AR, walaupun Komisi Pemberantasan Korupsi (KPK) dan Tim Pemberantas Tindak Pidana Korupsi (Timtas Tipikor) dibentuk tetap tidak 
mampu mengangkat nama Indonesia keluar dari kelompok negara terkorup di dunia tahun 2005 lalu. Sebab, yang dihajar hanyalah korupsi kecilkecilan, korupsi berskala jutaan dan miliaran rupiah. Korupsi triliun rupiah, tampaknya, tidak akan dikejar. Bila korupsi teriliunan itu dikuak, sangat mungkin petinggi-petinggi negara terkemuka juga akan terserempet (Jawapos. co.id, 1 Januari 2006).

Permasalahan pokok dari kasus ini yaitu adanya celah dan ruan dalam sistem politik serta perundang-undangannya, sehingga para koruptor bisa mengeruk keuntungan sebanyakbanyaknya secara pribadi. Hal ini dimulai dari korupsi kecil-kecilan, dibiarkan, dan meningkat dengan nominal yang lebih besar lagi, dibiarkan, dan begitulah begitu seterusnya. Terjadinya kasus pembobolan bank 14 tahun terakhir juga akibat adanya "fasilitas" dari para pejabat. Termasuk juga kaburnya banyak buronan korupsi kelas kakap, juga disebabkan karna praktek 'perselingkuhan' administrasi birokrasi antara pejabat dan pengusaha (yang sekaligus koruptor). Secara pasti permasalahan pemulihan ini dimulai dari penertiban pejabat terlebih dahulu, paling tidak celah atau ruang dalam sistem tersebut dapat ditambal dan diperbaiki. Di satu sisi yang lain, juga diperlukan persiapan sistem perundang-undangan yang mengikat dan kuat, serta tegas di dalam proses penegakannya. Yang tidak kalah pentingnya dalam upaya penuntasan kasus korupsi tersebut, yaitu adanya upaya kerja sama anta negara, terutama dalam hal tidak memberikan toleransi terhadap para buronan koruptor, -yang selama ini disebutsebut, bahwa negara Swiss lah yang paling aman sebagai tempat berlindungnya koruptor.

Swiss adalah salah satu negara yang dianggap surga bagi sindikat koruptor Indonesia. Namun, sepertinya cerita itu akan segera berganti. Kunjungan presiden Swiss ke Indonesia, yang merupakan pertama kali dalam sejarah kedua negara, membuktikan mulai 'interaktifnya' kepentingan kedua negara. Indonesia, sebagaimana disampaikan pemerintah, berharap Swiss dapat bekerjasama dalam melacak harta koruptor yang disimpan di beberapa bank di Swiss. Sambutan hangat diberikan Micheline Calmy-Rey, yang menegaskan tekad Swiss untuk membantu negara-negara di Asia dan Afrika dalam memerangi koruptor, khususnya Indonesia.

Swiss sebelumnya sukses mengembalikan harta jarahan dan mendeportasi koruptor ke pemerintah Filipina dan Nigeria. Ibarat mata rantai, serangkaian terobosan kebijakan dalam penanganan korupsi di atas merupakan satu kesatuan yang tersistem. Sangat disayangkan bila berbagai kemajuan yang telah dicapai tersebut tiba-tiba dihentikan atau dipatahkan untuk mengamankan kepentingan sekelompok kecil elite yang jelas-jelas menyengsarakan rakyat. Pengadilan Ad Hoc Tipikor merupakan satu mata rantai yang amat penting dalam kisah serial melawan korupsi itu (Zaenal, 2008).

Dengan demikian tindakan korupsi merupakan tindakan -yang tidak hanya bertentangan dengan nilai-nilai universal kemanusiaan, tetapi lebih dari itu, bahwa tindakan korupsi merupakan penghambat utama bagi proses terbentuknya sistem demokrasi dan gagalnya civil society. Sedangkan yang paling pokok dan prinsip sebagai dampak dari kasus ini adalah meningkatnya angka kemiskinan dan kriminalitas. Hal ini berarti bahwa demokrasi tidak serta merta dapat meningkatkan kesejahteraan masyarakat, tetapi sebaliknya, demokrasi dapat menyengsarakan rakyat, oleh kareena adanya sistem perapuhan dari dalam, sehingga dapat merobohkan unsurunsur utama di dalam proses pencapaian sebuah tujuan demokrasi itu sendiri.

Namun demikian, demokrasi tidak dapat dijadikan sebagai sasaran faktor utama, karena berjalan tidaknya sebuah sistem demokrasi bergantung dari penyelenggara, sistem penyelenggaraan dan proses penyelenggaraan demokrasi itu sendiri. Walaupun sistem demokrasi telah digunakan oleh hampir semua negara di dunia, tidak secara otomatis menjadi sebuah garansi sejahteranya sebuah masyarakat yang berdiam di dalamnya. Dengan demikian, apa yang dikonsepkan Abraham Lincoln tentang demokrasi; from the people, by the people, for the people, sebenarnya merupakan sebuah 'sasaran antara' yang memadukan antara ideologi sebuah negara dan peta politik kepentingan yang berorientasi pada kesejahteraan rakyat.

\section{KESIMPULAN DAN SARAN}

Demokrasi berfungsi sebagai sarana mencapai kehidupan yang lebih baik, bahkan demokrasi dapat dikatakan sebagai the second best system, yang tidak ada nomor satunya. Demokrasi seakan telah menjadi the only global order karena demokrasi nampaknya telah mencatatkan 
kemenangan historis atas bentuk-bentuk pemerintahan yang lain. Hampir mayoritas masyarakat dunia mengaku sebagai seorang demokrat dan setiap rezim politik di belahan dunia mengaku sebagai rezim demokrat.

Demokrasi secara umum memberikan peluang yang lebih memberikan keadilan bagi kehidupan bersama, ruang-ruang gerak yang lebih memadai bagi setiap manusia dan asosiasi manusia untuk mengembangkan kemanusiannya. Akan tetapi, demokrasi bagi negara ketiga tidak dapat serta-merta diterapkan, karena tidak hanya sebagai konsep (soft concept), melainkan juga perangkat keras dan lingkungan. Dengan demikian demokrasi sebagai sebuah strategi tidak hanya dipahami, tetapi juga sebagai proses politik modern (profesionally managed).

Untuk mewujudkan sistem demokrasi diperlukan sebuah kapasitas, agar penggerak demokrasi tidak justru menabrak rakyatnya sendiri. Selanjutnya, dibutuhkan agenda tanpa henti yang dilakukan oleh sebuah negara untuk mengembangkan kapasitas demokrasi tersebut melalui proses pembelajaran dan penguatan kelembagaan.

Demokrasi merupakan pilihan bangsa Indonesia dalam mewujudkan cita-cita kemerdekaan. Pilihan tersebut memang belum sepenuhnya mampu menghasilkan kesejahteraan bagi seluruh lapisan masyarakat seperti yang diharapkan. Akan tetapi dengan kenyataan tersebut, diharapkan tidak sampai melahirkan sikap skeptis terhadap sistem demokrasi. Karena hanya dengan kesungguhan dan tekad yang bulat dari smua pihak terkait, sistem demokrasi akan benar-benar membawa Indonesia ke depan pintu gerbang kemerdekaan yang sesungguhnya.

\section{DAFTAR RUJUKAN}

Barrington, M., Jr.,1966.Social Origins of Dictatorship and Democracy:Lord and Peasant in the Making of the Modern World. Boston:Beacon Press.

Budiyono, Z., A, 2008.Demokrasi Bukan Basa-Basi !, Jakarta. DCSC Publishing.

Culla, A. S., 1999.Masyarakat Madani:Pemikiran, Teori, dan Relevansinya dengan Cita-cita Reformasi. Jakarta:PT Raja Grafindo Persada.

Indeks Demokrasi Asia.2011. Potret Indonesia, Pusat Kajian Politik, Departemen Ilmu
Politik FISIP Universitas Indonesia (Puskapol) dan Center for Democracy and Human Rights (Demos).

Denny, J.A. 2006.Demokrasi Indonesia (Visi dan Misi), Jakarta. Pustaka Sinar Harapan.

Huntington, S. 1991. The Third Wave:Democratization in the Late 21th Century.

Przeworski, A. 1988. Democracy as Contingent Outcome, dalam Jon Elster and Rune Slagstad, Constitutionalism and Democracy. Cambridge.

Rachbini, D. J. 2008. Teori Bandit:RMBooks. Jakarta.

Randy, R. W. 2009. Tinjauan Kritis Atas Konsep Demokrasi Sebagai Sebuah Nilai Universal. Jakarta. hal191-228.

Robert, A. D.,1971.Polyarchy:Participation and Opposition (New Haven:Yale University Press.

Sen, A. 1999. Democracy as a Universal Values dalam Development as Freedom, Alfred Knopf Publishing. New Delhi.

Sorensen, G., 2003. Democracy and Democratization (Demokrasi dan Demokratisasi, Yogyakarta, Pustaka Pelajar.

Sorensen, G. 1998. Democracy and Democratization:Processes And Prospects In A Changing World. Westview.

Suyono, H. 2009, Demokrasi Pancasila. Jakarta. Nusantara Institute.

Urbaningrum, A. 2004. Melamar Demokrasi: Dinamika Politik Indonesia. Jakarta.

Wrihatnolo, R. R. 2009. Tinjauan Kritis Atas Konsep Demokrasi Sebagai Sebuah Nilai Universal. Jakarta.

Wrihatnolo, R. R. 2007. MembumikanMillenium Development Goals (MDGs) Kedalam KebijakanPembangunandiDaerah, dalam jurnal Perencanaan Pembangunan.

Yusron. 2009, Elite Lokal dan Civil society. Jakarta. Pustaka LP3ES.

\section{Makalah:}

Kartasasmita, G. 2008. (Ketua DPD Republik Indonesia),Strategi Pembangunan Ekonomi:Antara Pertumbuhan dan Demokrasi 2008.

Batubara, C. 2007.(Salah satu narasumber buku) Menelusuri Kembali Demokrasi Pancasila, Bab II "Pancasila \& Demokrasi". 
Madjid, N. Potensi Dukungan Budaya Nasional Bagi Reformasi Sosial-Politik Masa Depan", 2122 Agustus 1996

Francis Fukuyama, Social Capital and Civil society, disampaikan pada The IMF Conference on Second Generation Reforms, 1 Oktober 1999.

\section{Jurnal:}

Huntington. 1984."Will More Countries

Become Democratic?" Political Science Quarterly99, No.2.

\section{Media Online:}

Amin Rais, Gembar-gembor antikorupsi cenderung membosankan", Jawapos.co.id, 1 Januari 2006

KemiskinandiIndonesia,http:/ / www.indonesiainvestments.com/id/keuangan/ angka-ekonomi-makro/kemiskinan/ item301, tanggal 3 Pebruari 2016 
144 | Moh. Zaini, Kebijakan Pemberlakuan Politik Demokrasi ... 